\title{
On Asset-Liability Matching and Federal Deposit and Pension Insurance
}

Zvi Bodie

\begin{abstract}
Asset-liability mismatch was a principal cause of the Savings and Loan Crisis of the 1980s. The federal government's failure to recognize the mismatch risk early on and manage it properly led to huge losses by the Federal Savings and Loan Insurance Corporation, which had to be covered by taxpayers. In dealing with the problems now facing the defined-benefit pension system and the Pension Benefit Guaranty Corporation (PBGC), the government seems to be making some of the same mistakes it made then. Among the causes is the fallacious belief that because pension funds have a long time horizon the risk of investing in equities is negligible. In fact, the opposite is true. Moreover, for the PBGC, the mismatch risk is magnified by moral hazard and adverse selection. Distressed companies facing the prospect of bankruptcy have an incentive to underfund their pension plans and adopt risky investment strategies; healthy companies have an incentive to terminate their plans and exit the system. The paper explores some ways to limit the costs of a potential PBGC bailout.
\end{abstract}

Federal Reserve Bank of St. Louis Review, July/August 2006, 88(4), pp. 323-29.

\section{INTRODUCTION}

드 inancial crises have a nasty habit of recurring, but never in precisely the same way. The differences can obscure the similarities, which makes it difficult-but not impossible-to learn from our mistakes. In the 1980s we had a long and costly learning experience with deposit insurance-the Savings and Loan (S\&L) Crisis. It finally ended with a large taxpayer bailout and the dismantling of the Federal Saving and Loan Insurance Corporation (FSLIC).

Now we face a crisis with the federal corporation that guarantees private pensions- - the Pension Benefit Guaranty Corporation (PBGC). The current crisis did not follow from some perfect storm of unforeseeable factors. It was largely caused by the same factor that led to the S\&L Crisis and the demise of the FSLIC: a mismatch between assets and liabilities.

Perhaps the reason I was invited to speak at this conference is that long ago, in 1991, I explicitly warned that such a crisis might occur. ${ }^{1}$ So I want to express my deep gratitude to the organizers of this conference for giving me the opportunity to say, "I told you so."

\section{A BRIEF DIGRESSION ON THE COST OF FINANCIAL GUARANTEES}

Before discussing how and why the PBGC got into this mess, there is a fundamental point

1 The occasion was a conference held by the Federal Reserve Bank of Cleveland in May 1991. The proceedings are published in Sniderman (1993). Commenting on a paper delivered by Kathleen Utgoff, who had just left the job of executive director of the PBGC, I said this: "[Kathleen] seems reasonably confident that almost all of the major perverse incentive problems facing the [PBGC] have been fixed, while I do not. In particular, I am concerned that unless the PBGC can impose some restrictions on the pension fund investment practices of financially weak plan sponsors, it may well face a FSLIC-type crisis. Indeed, failure to understand the important role of investment policy in determining the exposure of the government guarantee fund was the critical factor in the severity of the FSLIC crisis. I believe that similar factors are at work in the pension arena, and understanding them may help to avert a crisis for the PBGC” (Bodie, 1993, p. 161).

Zvi Bodie is a professor of finance and economics at the Boston University School of Management.

(C) 2006, The Federal Reserve Bank of St. Louis. Articles may be reprinted, reproduced, published, distributed, displayed, and transmitted in their entirety if copyright notice, author name(s), and full citation are included. Abstracts, synopses, and other derivative works may be made only with prior written permission of the Federal Reserve Bank of St. Louis. 
that I need to establish about the cost of providing financial guarantees. ${ }^{2}$ Guarantees such as deposit or pension insurance oblige the guarantor to make the promised payment if the bank or pension fund fails to do so. The economic loss to the guarantor is equal to the difference between the promised payment on the guaranteed contract and the price received from the sale of the assets that are available from the issuer as collateral for this obligation. This difference is called the "shortfall." All assets of the liability issuer that the guarantor has recourse to seize are called "collateral."

To sustain itself, the guarantor must charge a premium large enough to cover both actuarial loss experience and operating costs. Viability is achieved by a mixture of adequate premiums, control of operating costs, and control of the frequency and the severity of shortfall losses.

For example, let us set the premium equal to the cost of a single guarantee. For simplicity, assume that there are no operating costs. If the value of collateral assets, $V$, exceeds the promised payments, $B$, the guarantor keeps the premium and pays nothing. But if the value of assets is less than the promised payments, the guarantor must pay the difference, $B-V$. The guarantor's maximum profit is equal to the premium plus interest earned from investing the premium prior to payment of losses or expiration of the guarantee. This maximum profit is diminished by the shortfall or loss experience from issuer defaults. The guarantor's profit function is thus given by

$$
P(l+r)-\max [0, B-V],
$$

where $P$ is the premium and $r$ is the interest rate.

The guarantor bears the full downside risk of the collateral assets. It does not, however, participate in the upside gains that an owner of those assets would receive. Because of this asymmetry, the guarantor's expected loss is an increasing function of the volatility (i.e., standard deviation) of the difference between the promised payment $B$ and the asset value $V$. Therefore, to sustain themselves as viable economic entities without crosssubsidies from other insured institutions or from taxpayer funds, the guarantor must charge a

\footnotetext{
2 This section is based on Merton and Bodie (1992).
}

premium that is directly related to the volatility of the difference between the market value of the guaranteed payment and the market value of the assets serving as collateral.

\section{THE CURRENT PENSION INSURANCE MESS}

The PBGC insures the pension benefits of the 44 million Americans covered by private definedbenefit pension plans. Traditional pension plans of the defined-benefit type have been declining in relative importance in recent years. Companies are (legally) terminating them and replacing them with "defined contribution" plans such as 401(k) plans that amount to tax-deferred private savings plans. The number of private defined-benefit plans peaked in the mid-1980s at 112,000. At that time, about 40 percent of American workers were covered by them. Over the past two decades, the number of plans has fallen to just over 31,000 plans, which cover only one worker in five. No large companies have started defined-benefit plans in recent years.

When a PBGC-insured pension plan is terminated with insufficient assets to pay the benefits promised to employees-typically, after an employer bankruptcy-the PBGC takes it over and makes up the shortfall. There is a cap on the insured benefit, however, which is currently $\$ 45,000$ per employee per year.

The expressed purpose of establishing the PBGC was to insure a minimum level of promised defined-benefit pensions against default risk of the plan sponsor. However, if firms can transfer their pension obligations to the PBGC, then the government effectively pays a portion of the workers' total compensation because these obligations are linked to workers' pay. The size of this government subsidy can be large. Similarly, PBGC insurance has served as a less visible way to guarantee the debt of financially troubled firms than guaranteeing the bonds issued by these firms.

By law, the PBGC is supposed to finance all of its operations from three sources: (i) the premiums it collects from companies that still sponsor defined-benefit plans, (ii) the assets it recovers from terminated underfunded plans, and (iii) the 


\section{Figure 1}

\section{PBGC's Net Financial Position}

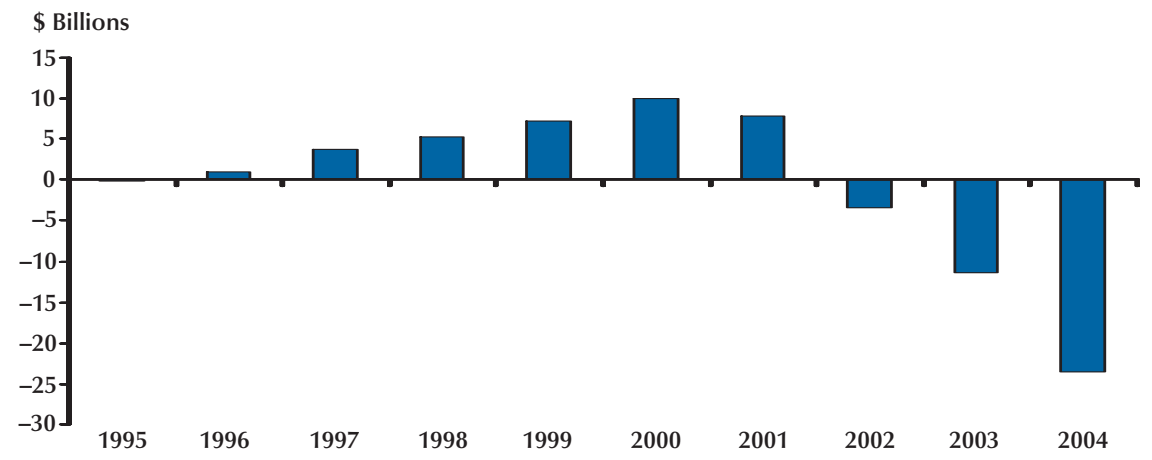

\section{Table 1}

\section{PBGC's Net Financial Position (billions of dollars)}

\begin{tabular}{lrlllllllll} 
Program & $\mathbf{1 9 9 5}$ & $\mathbf{1 9 9 6}$ & $\mathbf{1 9 9 7}$ & $\mathbf{1 9 9 8}$ & $\mathbf{1 9 9 9}$ & $\mathbf{2 0 0 0}$ & $\mathbf{2 0 0 1}$ & $\mathbf{2 0 0 2}$ & $\mathbf{2 0 0 3}$ & $\mathbf{2 0 0 4}$ \\
\hline Single-employer & -0.315 & 0.869 & 3.481 & 5.012 & 7.038 & 9.704 & 7.732 & -3.638 & -11.238 & -23.305 \\
Multi-employer & 0.192 & 0.124 & 0.219 & 0.341 & 0.199 & 0.267 & 0.116 & 0.158 & -0.261 & -0.236 \\
Both combined & -0.123 & 0.993 & 3.700 & 5.353 & 7.237 & 9.971 & 7.848 & -3.48 & -11.499 & -23.541
\end{tabular}

interest, dividends, and capital gains it earns on its accumulated reserves. Premiums come from a charge to plan sponsors of \$19 dollars per singleemployer plan participant and $\$ 2.60$ for multiemployer participants. ${ }^{3}$ There is also a variable premium charged to single-employer sponsors with significant underfunding. The charge is $\$ 9$ per $\$ 1,000$ of unfunded vested benefits.

Significantly, the funding requirements and premiums charged by the PBGC are completely unrelated to the way pension assets are invested. A plan sponsor with 100 percent invested in equities has the same funding requirement and pays the same premium as a sponsor with 100 percent in fixed-income securities.

The PBGC now has a big deficit to cover. In its annual report, the PBGC presents a balance-sheet measure called "net position," which amounts to

3 Since this paper was written, the premium was raised from $\$ 19$ to $\$ 30$ per insured person. For the most recent annual report, see www.pbgc.gov/workers-retirees/about-pbgc/content/page13176.html. its assets minus its liabilities evaluated at current market prices. The liability figure is the present value of the future benefits that have already become or are about to become an obligation of the PBGC as a result of bankrupt underfunded plans. If this net position is negative, it is a rough estimate of the extra money the PBGC would have to set aside today in the form of income-producing assets to satisfy all claims.

On November 15, 2004, the PBGC released its annual report for fiscal year 2004, which ended on September 30. It contains a financial summary showing the net positions for single-employer and multi-employer programs going back to 1995 (see Figure 1 and Table 1).

The trend is negative in both the singleemployer and multi-employer programs, but the magnitude of the problem is much larger in the former. In 1996, the single-employer program's net position was positive-that is, in surplusand it stayed positive until 2001, when it reached 
$\$ 7.7$ billion. But in the past three years, the ink has turned decidedly red: The deficit now stands at $\$ 23.3$ billion.

This deficit could get much bigger. As of the end of the 2004 fiscal year, the PBGC's estimate of the underfunding in plans sponsored by companies with credit ratings below "investment grade" - that is, at significant risk of default-was $\$ 96$ billion. But even the $\$ 96$ billion figure for struggling companies is not the upper limit on the possible deficit. The PBGC estimates that the total underfunding in single-employer plans exceeded $\$ 450$ billion, while multi-employer plans were under water to the tune of $\$ 150$ billion. ${ }^{4}$

Those who created the present mess are blaming a perfect storm of stagnant stock prices, low interest rates, and industrial restructuring for the PBGC's problems, as if nothing could have been done to prepare. But the current crisis did not follow from some unforeseeable perfect storm. I know this from personal experience: In the early 1990s, I was hired by the Department of Labor to analyze the financial health of defined-benefit pension plans. I concluded that there was a fundamental mismatch between the liabilities of these plans-future pension payouts-and the assets in which they were investing their reserves. This mismatch meant that even plans that were fully funded at the time could quickly become underfunded as a result of changes in interest rates or stock prices.

I submitted my report to the Department of Labor's Pension and Welfare Benefits Administration and briefed the executive director of the PBGC on my findings. I also made my conclusions known in the professional community. In an article published in the Journal of Financial Services Research in 1996-a time when the PBGC and most of the plans it insures had comfortable surpluses-I made this warning:

The possible "doomsday" scenario for the defined-benefit pension system would be an event such as a sharp and prolonged drop in stock prices that causes a sharp decline in the market value of pension asset portfolios.

4 The U.S. Congressional Budget Office (2005) estimates that the cost exposure of the government for federal pension insurance provided through the PBGC is currently about \$135 billion.
Underfunding becomes much more prevalent. Several major defaults of underfunded pension plans lead the PBGC to significantly raise premiums on the remaining plans in the system. Expectations of even higher premiums in the future lead sponsors of the well-funded plans to terminate their defined-benefit plans to avoid the PBGC "tax." They buy annuities to settle all benefits accrued under the terminated plans and replace them with generous definedcontribution plans, thus avoiding criticism from their employees or from the public. Ultimately, the United States could be left only with bankrupt defined-benefit plans with the benefits financed directly by taxpayers. (Bodie, 1996, p. 85)

It is worth noting that many of the pension plans that are weak today were fully funded in the late 1990s. Had they hedged their exposure to a decline in interest rates at that time, they would have easily survived the subsequent storm intact.

There are important similarities between the PBGC's current situation and the situation faced by the FSLIC in the 1980s. The FSLIC's problems began in the 1970s when interest rates became high and volatile. Even S\&Ls that held welldiversified portfolios of mortgages became insolvent in the environment of rising interest rates of the 1970s because the mortgages were long term with fixed rates, while their deposit liabilities were short term and rolled over at increasingly higher market rates.

Still more S\&Ls became insolvent in the late 1980s because the real estate market collapsed. Thus both of the market risks to which S\&Ls were exposed-interest rate risk and real estate risktook their toll. The biggest losses to the FSLIC were incurred not as a result of fraud or even of poorly diversified asset portfolios, but rather as a result of failure on the part of regulators to act quickly to stem the losses resulting from the assetliability mismatch.

In the case of the PBGC, the nature of the liabilities of private defined-benefit pension plans is very different from the short-term deposit liabilities that were insured by the FSLIC. Therefore, the type of assets that match those liabilities is different. The similarity is that in both cases there is a mismatch between the market-risk of the assets 
and liabilities that exposes the government guarantor to substantial shortfall risk.

Today, the PBGC appears to have been sucked into that doomsday scenario. Why was my warning, which was solicited by the government itself, completely ignored then, and why is it still being ignored by Congress in its proposed pension reform legislation?

The answer has its roots in a fundamentally flawed belief about the nature of stock market risk and reward, a belief that still guides the thinking and the practices of the vast majority of professional pension actuaries and investment advisors. It is the proposition that, although stocks are a risky investment in the short run, they are a safe bet in the long run. ${ }^{5}$

This mistaken proposition leads financial professionals to advise their corporate clients that they can significantly reduce the cost of funding their long-term obligations to definedbenefit plans by investing in diversified portfolios of stocks instead of matching the liabilities with a portfolio of bonds that delivers specified sums of cash at specified times.

The accounting profession has codified this fallacy in the way it treats pension expenses in company statements of profit and loss. Indeed, under current rules, if a company should choose to invest pension assets in bonds whose future cash inflows exactly match the pension benefits, the company would have to report higher pension expenses and lower profits than would an identical company that invests in stocks.

So what exactly is the fallacy? Consider a very simple example. Assume that ABC company has a defined-benefit plan for a single employee, Jane Jones. Jane has worked for the firm for a year and as a result has earned the right to a pension payment of $\$ 1,000$ when she retires 20 years from now. If the interest rate on bonds maturing in 20 years is 5 percent per year, the company would have to invest $\$ 376.89$ in such bonds today in order to be certain to have $\$ 1,000$ in 20 years to pay to Jane. Under U.S. pension law, the bonds would be held by a pension trust, so that even if $\mathrm{ABC}$ were to go bankrupt Jane would still receive her promised benefit.

${ }^{5}$ In fact, the opposite is true. This is shown in Bodie (1995).
The $\$ 376.89$ is the "present value" of the promised future pension benefit, and accounting logic dictates that it is the amount of ABC's pension expense in the current year. In each subsequent year, no matter what happens to interest rates or stock prices, the value of the bond will exactly match the pension liability. Underfunding is impossible in these circumstances (as long as the ability of the bond issuer to pay its debts was in no doubt), and the PBGC will never have to pay a dime to Jane.

But ABC's pension consultant insists that ABC consider an alternative. Because the pension payment is not due for another 20 years, ABC has the option of investing in stocks to earn an expected rate of return of 10 percent per yeara plausible figure based on past stock market returns. Sure, from year to year stock prices will fluctuate, but over two decades the ups and downs will cancel out. If it sets aside $\$ 376.89$ for Jane's pension, ABC could-in fact, should-record a profit on the difference between the 10 percent long-run expected rate of return on stocks and the 5 percent interest rate on the accruing pension benefit.

What is wrong with this reasoning? Fluctuations in stock prices do not necessarily cancel out over time, no matter how long the time period. And contrary to the conventional actuarial reasoning, the risk of falling short of the target is actually greater in the long run than in the short run.

To see why, one need only check how much it would cost for ABC to buy insurance against such a shortfall. (The policy would make up the difference between $\$ 1,000$ and the value of the stocks in the pension portfolio.) Both in finance theory and in practice, the price of such insurance (called a put option) increases with the length of the time horizon. ${ }^{6}$

In our example, the cost of insuring against a shortfall if the stock portfolio is worth less than $\$ 1,000$ in 20 years would be about $\$ 125$. So to keep the upside potential of the stock portfolio and still be certain that at least $\$ 1,000$ would be available to pay Jane, ABC would have to lay out $\$ 125$ in addition to the $\$ 376.89$ invested in stocks. And

6 See Bodie (1995) for a more complete explanation. 
this is assuming that all dividends from the stocks are reinvested. So investing in stocks instead of bonds does not lower the cost of the promised pension benefit unless Jane is obliged to bear the risk of not receiving it-or unless the PBGC is there to pick up the extra cost of guaranteeing the pension payout.

\section{WHAT TO DO}

Since the creation of the PBGC, many companies have terminated their defined-benefit plans and replaced them with less expensive definedcontribution plans, thereby shifting to retirees the risk of retirement portfolios that produce disappointing returns. Ironically, one incentive for doing this is the existence of PBGC insurance in its current form. The current system overcharges sponsors of healthy plans to subsidize the ailing ones. Thus we have a classic case of the law of unintended consequences: Insurance designed to strengthen the traditional pension system winds up accelerating its demise.

Congress is now wrestling with these issues as several pension reform bills are making their way through the Senate and House of Representatives. All of them include raising premiums, tightening the pension funding rules, improving the measurement and reporting of pension liabilities, and attempting to increase the discipline of private sponsors' funding decisions. Higher premiumsin particular, ones linked to the PBGC's risk exposure-would offset losses on future claims. More accurate measurement of plans' liabilities would make the existing funding rules and premium schedule more effective.

But none of the pension reform bills has a provision to take account of the asset-liability mismatch in setting PBGC premiums or to restrict the exposure of the PBGC by requiring closer matching. There are two basic ways to achieve this end. The first is for pension funds to invest directly in fixed-income instruments that match their pension liabilities. The second is by means of swap contracts, which are less intrusive and often less costly.
Swaps are used to either hedge risks, as in the case of interest rate swaps, or to insure against risks, as in the case of credit default swaps. A swap contract consists of two parties exchanging (or "swapping") a series of payments at specified intervals (say, every six months) over a specified period of time (say, ten years). The payments are based on an agreed principal amount (called the "notional" amount), and there is no immediate payment of money between the parties. Thus, the swap contract itself provides no new funds to either party.

Around the world today banks and investment companies use swaps extensively to manage their exposures to currency, interest rate, credit default, and equity market risks and to lower their transaction costs. Pension funds have so far made relatively little use of swaps. ${ }^{7}$ The advantage of a swap contract is that it is noninvasive. Company pension plans can continue to hold their equity portfolios but eliminate the mismatch with their liabilities with a debt-for-equity swap.

Consider a company with large pension liabilities, which are fixed in nominal terms and have long durations. The company could enter in a swap that exchanged returns on a stock market index for a fixed interest rate. If the company (or its designated fund managers) is particularly good at managing the equity portfolio, the swap would allow the firm to retain that value added. In this way, it could eliminate the market risk of the portfolio but retain the value-adding risk of the superior fund-management performance.

There is no shortage of potential counterparties for such a transaction; any professional investor seeking to increase its exposure to equity returns would be interested.

\section{REFERENCES}

Bodie, Zvi. "The PBGC: A Costly Lesson in the Economics of Federal Insurance: Commentary," in Mark Sniderman, ed., Government Risk-Bearing. Norwell, MA: Kluwer Academic Publishers, 1993, pp. 161-66.

Bodie, Zvi. "On the Risk of Stocks in the Long Run."

\footnotetext{
${ }^{7}$ See Bodie and Merton (2002).
} 
Financial Analysts Journal, May/June 1995, 51(3), pp. 18-22.

Bodie, Zvi. "What the Pension Benefit Guaranty Corporation Can Learn from the Federal Savings and Loan Insurance Corporation." Journal of Financial Services Research, January 1996, 10(1), pp. 83-100.

Bodie, Zvi and Merton, Robert C. "International Pension Swaps.” Journal of Pension Economics and Finance, March 2002, 1(1), pp. 77-83.

Congressional Budget Office. The Risk Exposure of the Pension Benefit Guaranty Corporation.

Washington, DC: September 2005;

www.cbo.gov/ftpdocs/66xx/doc6646/09-15-PBGC.pdf

Merton, Robert C. and Bodie, Zvi. "On the Management of Financial Guarantees.” Financial Management, Winter 1992, 21(4), pp. 87-109.

Sniderman, Mark, ed. Government Risk-Bearing. Norwell, MA: Kluwer Academic Publishers, 1993. 
